\title{
Donald Trump's political campaign rhetoric. A cognitive study
}

\begin{abstract}
Politicians recruit conceptual metaphors, as these means enable them to talk about abstract political problems in terms of more tangible and commonplace entities. This study aims to explore linguistic aspects of Trump's presidential campaign and is conducted in light of premises derived from Critical Discourse Analysis and Critical Metaphor Theory. The selected speeches were analyzed using a corpus research tool, i.e. Metaphor Identification Process was implemented. Donald Trump's campaign speeches were retrieved from internet sources. The period from January 24th, 2015 to October 20th, 2016 was chosen for compiling the primary corpus of 20 speeches. The qualitative analysis indicates that the President used metaphorical expressions frequently. The author of the article enumerates some grand metaphorical themes underlying Donald Trump's campaign speeches.
\end{abstract}

Keywords: Donald Trump, campaign speeches, conceptual metaphor, MIP, discourse.

\section{Background information}

Donald Trump's presidential election in 2016 gained the status of one of the most warlike and controversial campaigns in the history of the modern United States (Lakoff 2017). For this reason the aspects of Donald Trump's political message has attracted the interest of a great number of linguists who aim to examine it. Trump's presidential campaign sparked interest throughout the world as it ended with Donald Trump's victory. To the astonishment of many people, the businessman and political outsider who represented the Republican party won against the politically experienced Democrat candidate, Hillary Clinton. Thereby, on January 20th, 2017, Donald Trump became the 45th president of the United States of America.

There is little doubt that the success of Trump's campaign is to a large extent a matter of his unprecedented rhetoric. Donald Trump arouse strong emotions as his political remarks are controversial and geared at presenting him as a tough opponent. Indeed, Donald Trump's election campaign was full of bold remarks that may be compared to verbal attacks on the opposing candidates.

1 Address for correspondence: Department of Linguistics, University of Białystok, Pl. NZS 1, 15-420 Białystok, Poland. E-mail: martyna.awier@o2.pl 
The objective of this study is to examine linguistic strategies embedded in Donald Trump's portrayal of other candidates. The article, however, especially investigates how the interrelatedness of conceptual metaphors and discursive strategies shaped Donald Trump's political campaign discourse. The research intends to examine how language enabled Trump to delegitimize Clinton's credibility and it shows in what way Trump transmitted his ideology.

For the purpose of investigating the effectiveness of Donald Trump's campaign rhetoric, a compilation was chosen of ten speeches made by Donald Trump ranging from January 24th, 2015 to October 20th, 2016. This time span provided the possibility to examine Trump's election campaign rhetoric and arrive at generalizations concerning his electoral political discourse. All of the President's speeches analyzed in this paper were retrieved from internet sources.

Trump's campaign speech given in New York City on June 22nd, 2016 and his nomination speech delivered on July 21st, 2016 were singled out. These two speeches were chosen for detailed analysis because they are the most commented on of Trump's speeches that include bold and controversial remarks. These speeches provided an array of interesting linguistic aspects which facilitated observations. In order to avoid potential confusion concerning the methodology of the research, the following notation will be used: NYCS stands for Trump's New York City Speech given on June 22nd, 2016. Correspondingly, NAS is an abbreviation for Nomination Acceptance Speech delivered by Donald Trump on July 21st, 2016.

\section{Research methodology}

Before embarking on the analysis of Donald Trump's rhetoric, subject matters such as speeches, audience and addressee have to be commented on. The analyzed speeches were written in advance, but they were delivered in a spoken form. The purpose of the message was to persuade Americans that Donald Trump should become president. The addressor is the Republican candidate for presidency, namely Donald Trump. The addressee concerns all potential voters, i.e. Republican supporters and some undecided individuals.

At this stage, the governing procedure of the following research will be described. Firstly, the speeches underwent the process of thorough reading and, as a result, the main features of Trump's election discourse were identified. Next, I turned to the framework of conceptual metaphors. I decided that firstly I should check whether Trump employed verbal metaphorical expressions in his campaign speeches. To facilitate the study, the Metaphor Identification Procedure (MIP) was implemented as a research tool. Analysts who employ the MIP should not assume the existence of metaphors in advance. Metaphor scholars analyze linguistic expressions and decide which metaphorical item shows a contextual meaning that is not consistent with the basic meaning. The 
metaphor researcher has to detect whether there is some correspondence between the two meanings. Only at this point can conceptual metaphors be classified and grouped according to their common domains. Finally, systematic correspondences between conceptual domains were explored, followed by the grouping of metaphors according to the meaning detected in each example of metaphor usage.

\section{Metaphors and discourse turn}

Before George Lakoff and Mark Johnson's Metaphors We Live By (1980), metaphor research was disregarded and largely ignored for many years. Indeed, traditional scholars treated metaphor with suspicion and disdain. Plato ( $5^{\text {th }}-4^{\text {th }}$ century BC) and Hobbes (1651) are representatives of the empiricist tradition. Scientists criticized poets for using metaphorical, figurative language. Metaphorical expressions were identified as serious mistreatments of natural language that should be eschewed (see Grey 2000: 2). In this particular context, metaphor was seen as distortion of truth and it was considered best that poets and playwrights abstain from the employment of metaphorical expressions. Metaphors were thought to impede understanding of external reality, and as such, convention of the times held that the truth could only be achieved by means of literal language.

However, Lakoff \& Johnson's groundbreaking Conceptual Metaphor Theory (CMT) unconditionally refuted the formerly traditional approach to metaphor studies. Cognitive linguists introduced the standard view of metaphor in cognitive literature. First of all, relatively recent research provides the reason for placing a sharp division between the literal and figurative meanings in question (Barczewska 2017: 105). Indeed, a traditional approach towards literal and figurative forms of language seems to be at odds with central premises of the cognitive standpoint. Twentieth century linguists hold the view that metaphor is a major cognitive tool that resides in thought (not merely in words). Cognitive approaches concerned with metaphor recognize its conceptual character and treat metaphor as a transmitter or guider of human feelings, actions, thoughts, contemplations or behaviors (see Górska 2008: 15).

Lakoff \& Johnson extended metaphor's use beyond the linguistic level and they posited it at the conceptual level claiming that metaphors give structure to concepts. Cognitive scholars conclude that people understand abstract and diffuse conceptions in terms of more tangible and commonplace entities (see Kövecses 2002: 4). Thus, Lakoff \& Johnson argued that human thinking and reasoning patterns are deeply rooted in metaphors and people use metaphors in everyday life automatically, effortlessly and unconsciously (1980, quoted after Goatly 2007: 22).

There also exist some voices that question the groundbreaking character of CMT (see Fabiszak 2005; McGlone 2007). Traditional conceptual metaphor researchers neglect the metaphors evoked by real language users in authentic situations (Kövesces 2009: 80ff.). The growth of discourse studies and social context triggered metaphor researchers to 
seek authentic data, and led to metaphor researchers examining metaphors in authentic language use and real discourse (see Fabiszak 2007; Fabiszak \& Konat 2013). As a consequence, scholars noticed that CMT could also be faulted for the lack of social contextual sensitivity. This discovery resulted in discourse analysts stipulating that conceptual and discourse metaphor analysis should not be conducted separately.

Nevertheless, both metaphors and discourse are extremely intricate phenomena, presenting the condition of a methodological challenge to find one suitable theory that would be compatible with each and every instance of metaphor usage in spoken discourse. Cameron, for instance, perceives discourse in its dynamics and claims that metaphors are emergent. Linguistic metaphorical expressions arise from a repetitive use of the same verbal metaphors while talking about significant topics in a specific flow of discourse (Cameron 2010: 137). It means that the metaphors which reappear within a given piece of discourse are the most salient ones. In a similar vein Müller (2008) examines metaphors in discourse.

Müller (2008) brings into focus "sleeping" and "waking” verbal metaphors. Sleeping metaphors are believed to exhibit small activation potential, whereas a waking metaphor tends to be highly activated. The analysis of both linguistic and non-linguistic (i.e. gestures or pictures) instantiations of decoding meaning determine the activation level. The more cases of metaphor reiterations or gestures may be detected in a discourse, the more conspicuous and active metaphor becomes (see Müller 2008; Górska 2014). Consequently, metaphor undergoes the process of attention foreshadowing. It signifies that waking or active metaphors serve the purpose of profiling addressees' attention to the key features of an analyzed sentence.

Charteris-Black (2004: 20ff.) approaches metaphors from the discourse and CMT perspectives. Charteris-Black concurs that the emergence of persuasive metaphor is strictly connected with the occurrence of "semantic tensions", i.e. incongruence between both basic and contextual meanings. The scholar also assumes that corpora would facilitate the study of metaphor. Charteris-Black (2004: 31) defines a corpus as a collection of a great number of texts that are connected with one another and concern the same subject matter. Charteris-Black advises metaphor researchers to narrow down the domain that they are going to examine and conduct a research on one specific domain; for instance, they may analyze texts on politics or medicine.

Zinken coined the term "discourse metaphor," and defined it as a "framing device" in a particular discourse. Zinken outlines that discourse metaphors emerge from socio-cultural interactions and as such, are consequently part of a discursive reality. Discourse metaphors reflect the community's beliefs and practices. Zinken claims that metaphors are situation and context specific (for more details on discourse metaphors see Zinken 2007). 
Semino advocates the view that metaphors are genre-specific, claiming that there is a group of metaphors that is certain to reappear in a specific type of discourse genre. For instance, the metaphors in colonialist discourse differ from metaphors in education discourse (see Semino 2007).

Due to these reasons more and more researchers implement the Cognitive Discourse Analysis (CODA). CODA enables metaphor researchers to combine the framework of conceptual metaphors with discursive strategies. The proponents of CODA recognize Critical Discourse Analysis techniques which juxtapose with reoccurrence of analogical and emotionally loaded verbal structures. A successful integration of CODA allows for the examination of underlying ideologies of the speeches under analysis (see Wodak 2006).

\section{Metaphors in political discourse}

Metaphor scholars posit the view that because of this specific ability of metaphors, they play a special role in political discourse. They can easily promulgate particular ideologies and theories, while dismissing others. As it has been stated earlier by Lakoff \& Johnson's CMT and their successors, metaphors have an ambiguous nature. They may highlight certain aspects of a given domain, but simultaneously some elements may get backgrounded. Thus, Alice Deignan (2005: 24), a researcher of metaphors in corpus analysis, adopts the view that metaphors can, in fact, "distort" reality. Wolf \& Polzenhagen (quoted after Dirven et al. 2003: 268) force the view that "global ideological patterns may arise from the application of a particular metaphor and the neglect of alternative ones." Therefore, metaphor can be employed to achieve ends which may not be readily detectable at a superficial level and they may be exploited to benefit a given politician's personal aspirations.

American conservatives' (right wing) and liberals' (left wing) political language perfectly fits into the cognitive models proposed by Lakoff (see Cienki 2005: 281). Representatives of both political fractions reason about the election campaign message in terms of idealized cognitive family models. The most natural and common metaphorical model exploited in political discourse is that of the NATION IS A FAMILY. As Lakoff (2004: 5) elucidates, people tend to perceive and link large and abstract social groups (for instance 'nation') with small communities or families. Lakoff's Moral Politics (2002) reveals that American politics is organized in the vein of two contrastive and opposing nation metaphors; one is the Strict Father (SF) Family, and the second is the Nurturant Parent (NP) Family. Ultimately, these two models are linked by larger metaphors, i.e. the NATION IS A FAMILY, the GOVERNMENT IS A PARENT and the CITIZENS ARE CHILDREN (Lakoff 2002: 154). In accordance with the SF approach to nation, the world poses a danger to citizens. It means that vulnerable people are endangered with competitiveness and immorality. Such a crucial and vicious place evokes the immediate need for a strict father who will protect and instruct his innocent citizens. Lakoff's SF model values a traditional patriarchal family structure. As the name itself implies, 
the SF imposes the vision of a strong man - a father who is able to protect his family from dangers. Father possesses the most appreciated merit of authoritative advice and strength, so the mother and children should follow the father's instructions. The SF system voices discipline and punishment, and it promulgates that consistent moral behavior will bring prosperity.

The conceptual metaphor of MORALITY IS STRENGTH prevails in the SF model. This compound metaphor licenses the following metaphors: BEING GOOD IS BEING UPRIGHT and, respectively, BEING BAD IS BEING LOW (see Lakoff 2002: 71). Within a political domain, the SF's metaphor of morality is strength refers to politicians whose political activity is impeccable. Thus, viable politicians are perceived as reliable leaders that will provide prosperity for a country. And as it is well-known, a rich country translates in practice to a strong country. Correspondingly, all corrupted and immoral politicians are believed to be weak and unreliable people. Additionally, the SF model takes priority over the MORALITY IS PURITY and the IMMORALITY IS IMPURITY metaphors (Lakoff 2002: 92f.). Immoral deeds and corruption will cause damage to the whole society. When it comes to the free market, the pursuit of self-interest seems to be prioritized. As Lakoff (2004: 8) concludes, it pushes the emergence of the WELL-BEING IS WEALTH conceptual metaphor. Thus, the WELL-BEING IS WEALTH conceptual metaphor implies an ideological perception of the state. In practice it means that potential national profit should be measured in terms of money. WELL-BEING IS WEALTH triggers a string of conditional sentences that inserts the "if" clause. It allows politicians to propose some actions that would foster prosperity in the country. Yet, it has to be highlighted that self-reliance stands at the center of the SF model. Therefore, the well-being metaphor, understood in terms of one of the main tenets of the SF model, refers to self-sufficient citizens of a given state. The self-reliance frame seems to favor a lack of governmental intervention into the lives and financial fluidity of citizens. Social programs are rejected in the application of the SF model to politics.

The SF president frames himself as the highest moral authority that is in power to coach people and direct their attention to certain issues. The SF president has a mission to educate other individuals and countries about what is good or moral and what is wrong or immoral. It goes together with metaphorical conceptualization of the nation as a person (see Chilton \& Lakoff 1989; Musolff 2010). In turn, some neighboring countries may be metaphorically seen as friends, and other nations may be portrayed as rogue states or enemies. As the nation is personalized, America should take care of itself to remain within the framework of the health metaphor. Metaphorically speaking, America is presented as a strong and wealthy country (or person). It may be deduced that America is a mature country. Following on, this assumption implies the adult-child metaphor. It means that all other countries are underdeveloped and are worse off industrialized "children" that need America's help. If so, it appears that America is framed 
as a moral governor that is supposed to bring peace and strongly address the world's central problems.

Politicians tend to use so-called conflict metaphors (Charteris-Black 2004: 90ff.). Raison d'étre is to evoke a physical struggle for highly valued things such as fundamental rights or freedom, or to invoke the fight against negative phenomena such as poverty, unemployment and so forth. This strategy gives rise to conceptual metaphors, i.e. POLITICS IS CONFLICT or POLITICS IS WAR. Politicians are supposed to overcome all societal illnesses. Correspondingly, Kövecses (2002: 69) enumerates the following metaphors that shape contemporary political discourse: POLITICS IS WAR and POLITICS IS SPORT. As Kövecses elucidates, the conceptual metaphor of POLITICS IS WAR illustrates the fact that political leaders assume the role of military leaders. Politicians' words, comments and policies are equated with weapons. The POLITICS IS SPORT metaphor is closely related to the previous metaphor. Conceptualization of POLITICS in light of the SPORT domain seems to highlight competitiveness among political parties. The POLITICS IS SPORT metaphor predicts that political elections will be a fierce political event. Candidates compete against one another and this process is reminiscent of a RACE Or SPORTS EVENT.

\section{Metaphors in Trump's campaign speeches}

The Pragglejaz Group ${ }^{2}$ (2007: 13ff.) developed a procedure for the identification of metaphors in a given context and discourse. The researchers employed the Metaphor Identification Procedure (MIP). The MIP is a useful tool for metaphor investigators. The procedure involves guidelines which help the metaphor analysts recognize instances of metaphors in a discourse. Firstly, researchers manually dissect a given text in an attempt to decide whether there are some sentences which may be metaphorically loaded. Here, it is important to underline that scholars should never assume a preexistence of metaphors in a text. Linguistic investigators decide upon the issue of metaphoricity by comparing meanings of linguistic expressions. They have to check a basic meaning of a given item and then they can compare it with its contextual meaning. Contextual meaning is deduced from data analysis. The phrase may be regarded metaphorical when its basic meaning differs from a situation-driven meaning.

Yet, it has to be highlighted that the MIP does not eliminate subjectivity of a scholar's individual decisions and choices. The identification procedure merely reduces the risk of potential subjectivity. Indeed, the procedure and its explicit rules do not posit a clear problem solving path. For instance, functional words pose challenges for establishing their meanings. Yet, the Pragglejaz Group does not specify if idiomatic expressions,

2 Pragglejaz Group is a group of metaphor researchers. Peter Crisp, Ray Gibbs, Alan Cienki, Graham Low, Gerard Steen, Lynne Cameron, Elena Semino, Joe Grady, Alice Deignan, and Zoltan Kövecses are members of the group. 
fixed expressions and phrasal verbs should be decomposed or whether they should be examined as one lexical unit. For the purposes of this data analysis, it was decided not to separate fixed and idiomatic expressions or phrasal verbs. Therefore, is seems that the MIP allows some space for "free" choices while considering the step of deciding whether a given word is metaphorically loaded.

First of all, the PERSON metaphor stands out in Trump's election discourse. The overarching metaphor of the NATION/STATE IS A FAMILY underlies the presidential election campaign discourse of Trump. Trump exploits a metaphorization model of the United States as a family, where citizens are members of one big and united community. Obviously, it should be assumed that the head of this metaphorical family (i.e. nation) is the President. The NATION/STATE IS A FAMILY is subjected to further conceptualization, namely that of the NATION/STATE IS A PERSON, which seems to pervade Trump's election rhetoric. Consider the following examples which illustrate the NATION/STATE IS A PERSON metaphor:

(1) Then she [Hillary Clinton] let China steal hundreds of dollars in our intellectual property (...) (NATION IS A PERSON) [NYCS]

(2) Her [Hillary Clinton] decisions spread death, destruction and terrorism everywhere. (DECISION IS A PERSON) [NAS]

(3) She [Hillary Clinton] supported the job killing trade deal with South Korea. (TRADE DEAL IS A PERSON) [NAS]

PERSON metaphor facilitates Trump's presentation of America as an ill and sad person that needs a moral and reliable leader. Trump explains that he is the only person that can help America "recover" and solve its problems. Interestingly, being an active observer of American political life, Lakoff amplified the scope of the NATION/STATE IS A FAMILY. Indeed, Lakoff modified this conceptual metaphor and adjusted it to contemporary reality renaming it as the PRESIDENT IS A NATION (Lakoff 2016a). In this case study it takes the form of the TRUMP IS A NATION conceptual metaphor. On this account, Americans may be equated with the followers of Trump and the desires or hopes of the American people appear to be Trump's needs. Thus, the phrases America first and America's interest first begin to be linguistic manifestations of the TRUMP IS A NATION conceptual metaphor. They signify that, in fact, it is Trump's interest that is of primary importance. It seems that the PERSON metaphor serves as a platform for Trump's version of America. Trump vilifies his enemies. The role of the enemy should be ascribed to Trump's political opponent, i.e. Hillary Clinton. The FORCE metaphor and its linguistic realizations seem to introduce a war-like election campaign discourse. FORCE metaphors are denoted by verbalized forms of dynamic forces, such as let, cause, help, continue, or stop. FORCE metaphors serve to show the process of interaction of abstract entities (which 
are conceptualized as physical objects) with external forces. FORCE metaphors usually concern exertion of force, resistance to it or impediments and problems that particular force may encounter.

The EVENTS ARE ACTIONS is a salient entailment resulting from the FORCE metaphor. Given that events originate from the exertion of external forces, it has to be concluded that events are conceived of in terms of actions. In the case of such conceptualization, an object is materialized in terms of motion that has been caused by the forceful agent. The EVENTS ARE ACTIONS conceptual metaphor accounts for the cases of reification and objectification as usually it imputes the agency to some intangible objects (Turner 1994: 162). Consider these examples:

(4) Her bad instincts and her bad judgment (...) are what caused the disasters unfolding today (HILLARY CLINTON'S MISTAKES ARE A DESTRUCTIVE FORCE) [nas]

(5) I have visited the cities and towns across America and seen the devastation caused by the trade policies of Bill and Hillary Clinton (POLICY OF HILLARY CLINTON IS A DESTRUCTIVE FORCE) [NYCS]

Selected metaphors from Trumps' election speeches lead us to the conclusion that the EVENTS ARE ACTIONS metaphor propels a reluctance towards the policy of "other" candidates (especially Hillary Clinton). Trump's rhetoric creates a negative perception of Hillary Clinton as a politician. I would even dare to say that Trump portrays Hillary Clinton and her agenda as a destructive force that will ruin American policy. It entails an obvious and self-serving inference that Trump is the only right choice in the incoming election.

The second important submetaphor of FORCE metaphors is the CAUSES ARE FORCES. Linguistic manifestations concern the aspect of motion and some external forces that seem to be in charge of moving an abstract entity. In fact, it concerns the motion of an entity from one point to another and, more to the point, it takes the form of giving or taking away a given entity or object. Given this fact, we can further conclude that the CHANGES ARE MOVEMENTS OF POSSESSIONS, which induces potential gains or losses. Therefore, we can manipulate that metaphor and can easily deduce its entailment the ACTIONS ARE SELF-CONTROLLED ACQUISITIONS OR LOSSES. Thus, purposes are conceived of in light of obtaining desired objects and, accordingly, ACHIEVING A PURPOSE IS ACQUIRING A DESIRED OBJECT. Let us analyze these excerpts:

(6) She will keep our rigged system in place (LACK OF MOTION IS LACK OF CHANGE OR ACQUISITION) [NAS]

(7) She [Hillary Clinton] gets rich by making you poor. (CAUSES ARE FORCES) [NYCS]

(8) We can't hand over our government to someone whose deepest, darkest secrets may be in the hands of our enemies. (LACK OF MOVEMENT IS ACQUIRING A DESIRED OBJECT) [NYCS] 
It is clearly seen that FORCE metaphors shape political discourse. They trigger negative emotional judgments concerning opposition policy and specifically in the subject matter at hand, they created an image of Trump as a forceful agent that has the power to change things. Suffice it to mention that Trump promised to overturn all of Clinton's contracts he deemed unfavourable and create a great number of jobs. Trump promised the return to a moral path for American society and to eliminate any deviant behaviors from generally established rules.

It is also noticeable that the MORALITY conceptual metaphor underlies Trump's discourse. Moral people, in this case study, politicians, should be distinguished by their morality and praiseworthy actions. Moral politicians are seen as strong and responsible individuals that will be capable of governing the country and people. Moral and reliable leaders will overcome all potential hardships and they will lead a successful and reasonable policy. Thus, American citizens should entrust power with moral and strong politicians. This leads to the MORALITY IS STRENGTH and the MORAL POLITICIANS ARE STRONG conceptual metaphors.

Correspondingly, immoral politicians are paired with negative connotations intensified by the IMMORALITY IS IMPURITY conceptual metaphor. Immorality conjures up an image of politicians that cannot be trusted and should not be given power. Amoral politicians are seen as destructive and inappropriate candidates for being president of the United States. Amoral politicians make mistakes and their policy is full of poor decisions. In the long run, the actions of amoral politicians might destroy the entire harmony and natural order in the country. Poor management of the national budget may result in serious financial loses. Hence, the MORALITY IS STRENGTH and the MORAL POLITICIANS ARE STRONG conceptual metaphors dictate the emergence of the IMMORALITY IS WEAKNESS and the IMMORAL POLITICIANS ARE WEAK. These conceptual metaphors are illustrated below:

(9) Hillary Clinton is a world-class liar. (HILLARY CLINTON IS IMMORAL) [NYCS]

(10) Hillary Clinton's time as Secretary of State - a disgraceful performance for which she should not be congratulated, but rather scorned. (HILLARY CLINTON IS WEAK AND IMMORAL POLITICIAN) [NYCS]

(11) Then she [Hillary Clinton] let China steal hundreds of billions of dollars in our intellectual property. (CHINA IS AN IMMORAL PERSON, CHINA IS AN EVIL) [NYCS]

(12) (...) the communities crushed by our horrible and unfair trade deals. (A TRADE DEAL IS AN IMMORAL PERSON) [NAS]

On the whole, the above-discussed examples of the MORALITY conceptual metaphor show that amoral politicians should be nullified and purged from the country. The workings of the MORALITY conceptual metaphor employed in Trump's discourse lies behind an adverse social perception of Hillary Clinton's "immoral” policy. Amoral politicians (such as Clinton and her agenda) are usually selfish and they are oriented towards 
self-interest so they are inclined to corruption. Their political activity is confined to their own enrichment at other citizens' cost. In that sense, we can come up with yet another conceptual metaphor, namely that POLITICS IS TRADE as it is strictly and exclusively oriented towards amassing wealth. Such politicians tend to neglect both the citizens and the country's primary needs. At this point it is of pertinence to mention the so-called "LEAK" metaphor (Lakoff 2016a). It juxtaposes with the CORRUPTION IS IMMORAL conceptual metaphor and it concerns Clinton's breach of confidential national security. Trump continuously evokes Clinton's inclination for bribery and that she sold confidential information to foreign governments.

Finally, the MORALITY IS ESSENCE yields a virtue of MORALITY metaphor. Here, MORALITY is seen as an abstract entity that is responsible for harmony and the so-called law and order. If we accept this view, then, IMMORALITY becomes a single departure or deviance from this wholeness (morally accepted and permissible social rules). Trump skillfully crafts his speeches in such a way that shows destruction has been caused by the immoral and inappropriate policy of Hillary Clinton. It is the author's opinion that in the analyzed corpus it is the lack of wholeness which is at issue in the MORALITY metaphor. It creates the need for implementation of instant action that will impede the harmful effects of moral defiance. Trump consequently emphasizes that he is the only one - he is the father - who will restore moral standards and save America.

Health and disease as source domains typically operating within the context of talking about the human body. Nevertheless, HEALTH and ILLNESS may also be applied to political and economic spheres. DISEASE and HEALTH metaphors should be scrutinized in the framework of the STATE/NATION IS A PERSON. Firstly, it is evident that a person may experience illness and then there is a necessity for medical treatment. In politics, the state assumes the role of a patient. If the state were afflicted with any disease, the government would help it. These assumptions lead to the SOCIETY IS A PATIENT and the GOVERNMENT IS A DOCTOR conceptual metaphors. Let us examine the following examples:

(13) In short, Hillary Clinton's tryout for the presidency has produced one deadly foreign policy disaster after another. (...) (CLINTON'S FOREIGN POLICY IS A LETHAL DISEASE) [NYCS]

(14) This is the legacy of Hillary Clinton: death, destruction and weakness. (WEAK AMERICA IS ILL AMERICA) [NAS]

The logic of Trump's employment of health and disease metaphors lies behind the possibility of creating an image of America as an ill person that suffers from serious physical pain and needs immediate help. Notably, America is threatened with Clinton's policy that is conceptualized as a disease. Consequently, HEALTH and DISEASE metaphors appear to be in a partial consonance with the MORALITY metaphor. As Lakoff (2006) notes, immoral deeds seem to spread in the same way as diseases do. 
A plethora of politicians resort to SPORT metaphors. Gibbs (2017: 146) notices that Trump's language produces evidence of the employment of the phrases and words coming from boxing matches. This entails the emergence of the POLITICS IS A GAME conceptual metaphor, and subsequently, POLITICS IS A SPORTS GAME. Trump's rhetoric exploits the POLITICS IS BOXING conceptual metaphor. The domain of SPORT allows Trump to present the political election campaign as a competition which needs strong "players." Thus, the politician becomes a boxer and political events may be compared with fights in a boxing match. Consider the examples:

(15) I am running for President to end unfairness (...). (PRESIDENTIAL ELECTION IS SPORT) [NYCS]

(16) I can be your champion in the White House. (...). (BEING A PRESIDENT IS BEING A CHAMPION) [NYCS]

The WAR domain is productive and its linguistic realizations are deeply rooted in political discourse. The WAR metaphor is concretized in the form of POLITICS IS WAR. The whole presidential electoral campaign is a metaphorical fight against political opponents (in this case Hillary Clinton). Trump also exploits a combative rhetoric to prove that he is a strong boxer or soldier who will defend America and its citizens from all potential threats against national welfare and security. Mainly, Trump desires to fight against Hillary Clinton and the widespread phenomenon of corruption. He wants to counteract the effects of unemployment and help downtrodden Americans. The POLITICS IS WAR metaphor is employed in the excerpts given below:

(17) The choice in this election is a choice between taking our government back from the special interest, or surrendering our last scrap of independence. (ELECTION IS WAR) [NYCS]

(18) Brain William's career was destroyed for saying far less. Yesterday, she [Hillary Clinton] even tried to attack me. (POLITICS IS WAR) [NYCS]

(19) The first victims of her radical policies will be poor African-American and Hispanic workers. (POLITICS IS WAR) [NYCS]

(20) Hillary Clinton, who already has the blood of so many on her hands. (POLITICS Is WAR) [NYCS]

Trump crafts an image of war, hence America's land becomes a victimized battle field.

\section{Discursive strategies structuring Donald Trump's campaign message}

Van Dijk's advises us to analyze political speeches according to certain criteria, which he presents in the form of the so-called ideological square. The ideological square extracts the context of an analyzed text and it allows key features to stand out in political passages. To begin with, van Dijk (1997: 13) concludes that it is relevant to analyze the semantic structure of a sentence, i.e. to examine "thematic roles" and "topicalization." It 
demands the analysis of agents (politicians, high officials, presidents), patients (receivers), purpose and action (passing law, persuading, legitimization). In this present usage, discourse is viewed in light of texts or speeches made by politicians. Discourse scholars must therefore involve participants (voters, interest groups, opponents, demonstrators and so forth) in a political discourse analysis.

Another way of looking at political discourse is by defining the actions and the ways of achieving intended goals and implementing certain practices, i.e. legislating or governing (van Dijk 1997: 13f.). Again, it has to be kept in mind that political discourse cannot be separated from its context as officials only speak in a political manner during particular communicative events, ranging from parliamentary sessions to electoral campaigns.

Another predicate of political jargon is the investigation of "semantic polarization." Politicians resort to two sets of first person pronouns, which include singular and plural forms. The pronouns us and our are paired with positive evaluations, while they or them are carriers of negatively loaded meanings. The language of politicians tends to be full of long descriptions drawing on altruistic deeds of the speakers and, in reverse, there are thorough and long accounts and stories of bad actions undertaken by the opposition (van Dijk 1997: 27). Speakers are inclined to the technique of emphasizing their own good actions and dredging up all unsavory things that have been done by the opposing political party. Indeed, the use of pronouns creates a vision of solidarity or power. Pronouns may easily change meaning and shift the perspective, depending on given circumstances and context (Bloch 1975: 207). The analysis shows that pronouns employed in political speeches indicate responsibility for actions. The first plural pronoun they enables Trump to place Hillary Clinton as the focal point of responsibility.

The usage of the first person plural pronoun we inserts the notion of community and solidarity with listeners. Addressing pronouns such as: we, us, our or ours posits the speaker and listener in the same space and bonds their mutual understanding. Most importantly, it also fosters the feeling of trustworthiness. The advantage of plural pronouns is the fact that politicians may reject responsibility for adverse decisions. It is especially useful while making controversial decisions or taking radical measures. Using first person singular pronouns $I$, me, myself, or mine, however, helps politicians to indicate their commitment and interest. As it may be easily observed, first person pronouns tend to be employed while talking about success and positive actions (Beard 2000: 45). Nevertheless, an orator has to be acutely aware of the choice of pronouns as the overuse of first person singular pronouns may, in fact, create a negative vision of the speaker. In this manner, a politician may be framed as a person who boasts about their deeds and disregards other people. As Bloch (1975: 206) maintains, pronouns can manipulate social reality and assume "a masking functions in the verbal strategies; that is, they may be used to hide, or seek to promote, a particular mediated version of social reality." 
Donald Trump resorts to discursive strategies to gain the support of the public. First of all, Trump exploits the technique of legitimizing himself as a credible president-tobe of America by creating an image of a strong leader. He implements assertions that are full of statistical information and inform Americans about national problems. Interestingly, Trump offers immediate solutions to these problems. As Cap (2008: 24) signals, these solutions may be reckless and controversial; however, Americans will accept them. Trump embraces an argumentative discourse in a skilful way. In the beginning, he expresses plain facts and later on starts to introduce future plans and speculations. In this scenario, even Trump's predictions are unconsciously accepted as facts by the addressees.

It seems that Donald Trump communicates his objectives and goals in an extremely conscious and deliberate manner. Thus, Trump's language practice may be compared to a progressive flow of well-thought out assertions. Trump leads with simple statements expressing his faith in Americans and America, and then he follows up by activating his addressee's desire for prospective goals. Finally, Trump instructs the audience on the plan he intends to implement to fulfil his promises (Cap 2008: 25). Consider the following example:

(21) I have joined the political arena so that powerful [sic] can no longer beat up on people who cannot defend themselves. Nobody knows the system better than me, which is why I alone can fix it. I have seen firsthand how the system is rigged against our citizens, just like it was rigged against Bernie Sanders - he never had a chance. But his supporters will join our movement, because we will fix his biggest issue: trade deals that strip our country of its jobs and wealth. [NAS]

Finally, Trump also takes advantage of the first person plural personal pronoun we. Surprisingly, Trump's use of we juxtaposes with the use of the first person singular pronoun I. By using the first person plural pronoun, Donald Trump identifies himself with the audience. However, the first person singular pronoun singles Trump out as a "performer" of actions. Therefore, Trump positions himself as the only one who steps out to confront problems. The usage of pronouns in this way reinforces Trump's reliability and credibility, which is attested by Trump's statement:

(22) I'm with you, I will fight for you, and I will win for you. To all Americans tonight, in all of our towns, I make this promise: We will make America strong again. We will make America proud again. [NYCS]

Politicians tend to manipulate the proximity of some threatening and dangerous events. Thus, they resort to the strategy of delegitimization. Trump pursues a technique of negative-presentation of others. He criticizes Hillary Clinton and continuously 
marginalizes her role. Yet, Donald Trump enumerates all threats (i.e. China, the wave of globalism, unfair trade deals, ISIS, terrorism) and he seems to play with their proximity. Trump's rhetorical discourse gives Americans the impression that threats are imminent.

The strategy of delegitimization follows the insertion of the third person plural personal pronoun they. Consider the following example:

(23) [IMMIGRANTS] They are being released by the tens of thousands into our communities with no regard for the impact on public safety or resources. [NAS]

(24) Big businesses, elite media and major donors are lining up behind the campaign of my opponent because they know she will keep our rigged system in place. [NYCS]

The third personal plural pronoun aim at an adverse presentation of a political oppressor and enemies of the United States. By using they, Donald Trump usually points at corrupted people from Washington, foreign countries, immigrants or ISIS.

The strategy of delegitimization seems to transgress van Dijk's ideological square. One of the most blatant example of negative representation of "other" candidates is seen in this example:

(25) If I am elected President, I will end the special interest monopoly in Washington, D.C. The other candidates [sic] in this race has spent her entire life making money for special interests and taking money from special interests. [NYCS]

Donald Trump resorts to the discursive strategy by ascribing positive self-evaluation and negative evaluation of other candidates. The account of a politician's moral deeds stands in sharp contrast to Hillary Clinton's political steps. The recruitment of such a technique allows Trump to vilify the policy of Hillary Clinton.

\section{Conclusion}

A close reading of the selected speeches shows that Trump employs a plethora of discursive techniques in his presidential campaign message. More specifically, positive selfpresentation and vilification of other candidates reappear within Trump's discourse and, consequently, discursive strategies allow Trump to legitimize his message. The analyzed data explicitly show that a great number of conceptual metaphors occur in the speeches delivered by Donald Trump in the course of his presidential election campaign. The study also shows that Trump resorts to conceptual metaphors that underlie people's comprehension of abstract concepts. It may be concluded that Donald Trump uses highly conventionalized and well-entrenched metaphorical expressions that evoke simple conceptual metaphor structures. Donald Trump uses vocabulary from everyday domains and it makes his message more accessible and easier to process 
and understand. Trump frequently resorts to PERSON metaphors. They allow the statesman to depict America as a living person. Additionally, these metaphors highlight the significance of context. Donald Trump frames America as a metaphorical person. In this particular case, America assumes the role of a child and consequently the presidential candidate prompts the need of a father or a leader. Trump consistently refers to domains of HEALTH and ILLNESS to show that both America and its citizens physically suffer and need help. The research demonstrates that Trump's rhetoric reflects the main features of the Strict Father model. Trump conceptualizes America as a person and recruits MORALITY metaphors. Due to the implementation of said MORALITY metaphors, Trump paints a contrast between his own moral policy and the immoral and disloyal political steps of Hillary Clinton. Donald Trump also recruits a great number of SPORT and WAR metaphors. They create an image of Trump as a winner who will gain beneficial trade deals for America. Trump is a competitive and combative person, and as a parental figure he feels obliged to defend Americans and America's values. Verbal insults of other candidates prove Trump's strength. It may be concluded that language helps Trump to wield power. This linguistic discursive study indicates that metaphors underlie political discourse and human abstract reasoning. Conceptual metaphors exist in everyday speech and in time they become conventionalized linguistic expressions. Empirical research shows that the examination of language is an interdisciplinary task. First of all, understanding the meaning requires additional contextual and social information. Thus, the investigation of conceptual metaphors should not be conducted separately from corpus and discourse methodologies.

\section{References}

Barczewska, S. 2017. Conceptualizing Evolution Education. A Corpus-Based Analysis of US Press Discourse. Newcastle upon Tyne: Cambridge Scholars Publishing.

Beard, A. 2000. The Language of Politics. London: Routledge.

Bloch, M. (ed.). 1975. Political Language and Oratory in Traditional Society. London/New York/San Francisco: Academic Press.

Cameron, L. 2010. The discourse dynamics framework for metaphor. In: L. Cameron \& R. Maslen (eds.), Metaphor Analysis. Research Practice in Applied Linguistics, Social Sciences and the Humanities, 77-98. London, Oakville: Equinox.

Cap, P. 2008. Towards the proximization model of the analysis of legitimization in political discourse. Journal of Pragmatics 40: 17-41.

Charteris-Black, J. 2004. Corpus Approach to Critical Metaphor Analysis. Basingstoke: Palgrave MacMillan.

Charteris-Black, J. 2005. Corpus Politicians and Rhetoric. The Persuasive Power of Metaphor. Basingstoke: Palgrave MacMillan. 
Chilton, P. \& Lakoff, G. 1989. Foreign policy by metaphors. Center for Research in Language 3/5: 2-19.

Cienki, A. 2005. Metaphor in the 'Strict Father' and 'Nurturant Parent' cognitive models: Theoretical issues raised in an empirical study. Cognitive Linguistics 16: 279-312.

Deignan, A. 2005. Metaphor and Corpus Linguistics. Amsterdam: John Benjamins.

Fabiszak, M. 2010. Vilification of the enemy: Different enemies, the same linguistic strategies. In: D. Stanulewicz, T. Wolański \& J. Redzimska (eds.), Lingua Terra Cognita II: A Festschrift for Professor Roman Kalisz, 73-97. Gdańsk: Wydawnictwo Uniwersytetu Gdańskiego.

Fabiszak, M. \& Konat, B. 2013. Zastosowanie korpusów językowych w językoznawstwie kognitywnym. In: P. Stalmaszczyk (ed.), Metodologie językoznawstwa. Ewolucja języka. Ewolucja teorii językoznawczych, 131-142. Łódź: Wydawnictwo Uniwersytetu Łódzkiego. Gibbs, R. W. 2017. Metaphor Wars. Conceptual Metaphors in Human Life. New York: Cambridge University Press.

Górska, E. 2008. Four arguments for patterns of metaphorical thought. Acta Philologica 35: 15-31.

Górska, E. 2014. Dynamiczne podejście do metafory. Prace Filologiczne LXIV/2: 109-122.

Grey, W. 2000. Metaphor and meaning. Minerva 4: 1-8.

Lakoff, G. 2002. Moral Politics. How Liberals and Conservatives Think. Chicago: University of Chicago Press.

Lakoff, G. 2004. Don't Think of an Elephant!: Know Your Values and Frame the Debate The Essential Guide for Progressives. White River Junction. Vermont: Chelsea Green Publishing Company.

Lakoff, G. 2006. Thinking Points: Communicating Our American Values and Vision. New York: Farrar, Straus and Giroux.

Lakoff, G. 2008. The neural theory of metaphor. In: R. Gibbs (ed.), The Cambridge Handbook of Metaphor, 17-38. Cambridge/New York: Cambridge University Press.

Lakoff, G. 2016a. How to help Trump. http://georgelakoff.com/2016/12/15/how-to-helptrump/ (2 May 2019).

Lakoff, G. 2016b. Understanding Trump's use of language. http://georgelakoff.com/2016/08/19/ understanding-trumps-use-of-language/ (2 May 2019).

Lakoff, G. 2017. The president is the nation: The central metaphor Trump lives By. http://georgelakoff.com/2017/08/01/the-president-is-the-nation-the-central-metaphor-trump-lives-by/ (2 May 2019).

Lakoff, G. \& Johnson, M. 1980. Metaphors We Live By. Chicago: University of Chicago Press.

Pragglejaz Group. 2007. MIP: A method for identifying metaphorically used words in discourse. Metaphor and Symbol 22/1: 1-39. 
Turner, M. 1994. Reading Minds: The Study of English in the Age of Cognitive Science. Princeton, NJ: Princeton University Press.

Van Dijk, T. A. 1997. What is political discourse analysis? Belgian Journal of Linguistics 11: 11-52.

Wodak, R. 2009. Language and politics. In: J. Culpeper, F. Katamba, P. Kerswill, R. Wodak \& T. McEnery (eds.), English Language: Description, Variation and Context. A definitive new textbook in English language, 577-592. Houndmills: Palgrave Macmillan.

\section{***}

Martyna Awier is a PhD student at the University of Białystok, Poland. Her academic interests are in the areas of cognitive linguistics and discourse studies. Her current research focuses on conceptual metaphors and Critical Discourse Analysis. 